\title{
Low serum betaine levels as a potential biomarker for type 2 diabetes mellitus in patients with coronary artery disease
}

\section{Fei Guo}

xiangya hospital, central south university

\section{Xueting Qiu}

xiangya hospital, central south university

\section{Yuanting Zhu}

xiangya hospital, central south university

Zhirong Tan

xiangya hospital, central south university

Dongsheng Ouyang ( $\nabla 01940 @ c s u . e d u . c n$ )

Zhenyu Li

xiangya hospital, central south university

Original investigation

Keywords: CAD, T2D, betaine, biomarker

Posted Date: March 10th, 2020

DOI: https://doi.org/10.21203/rs.2.24351/v2

License: (c) (1) This work is licensed under a Creative Commons Attribution 4.0 International License.

Read Full License 
The authors have withdrawn this preprint from Research Square 